various parts of the earth within different seasons.-Prof. Krayevitch, who has undertaken a series of investigations on the very small changes of pressure of the air in connection with changes of weather, exhibited his new graphic very sensitive barometer, the column of which consists of water and mercury, and which amplifies $\mathrm{r}_{40} \mathrm{O}$ times the oscillations of a common mercury barometer.-Prof. Egoroff has begun a series of researches into the atmospherical lines of the solar spectrum. As known, several of them are due to the presence of water-dust in the atmosphere, and Ångström supposed that several other lines (A, B, and $a$ ) depend upon the presence of carbonic acid and nitrogen. The experiments of M. Egoroff show that neither of these two gases modifies the solar spectrum, even when the rays go through a sheet five metres thick of gas.

In other branches of physics we must but notice the most important work, by Prof. Tchebysheff, on centrifugal regulators; the researches by M. Sloughinoff on the calorific capacity of gases; by Prof. Petrushevsky on the velocity of evaporation of liquids with reference to the coefficients of cohesion of these liquids and to the molecular pressure; on the true atomical heat capacity, by M. Stelson, who arrives at the conclusion that the theory of a constant atomic heat-capacity is not true for many gases; and by M. Sloughinoff, on the powder-state of bodies, and on the changes of the internal energy of solids and fluids under the influence of exterior forces.

We notice also the communication by M. Lebedzinsky on an improved microscope with liquid lenses, which gives enlargements from 50 to 200 times, and is very cheap; and by $M$. Argamakoff on lighting and heating by means of pulverised hydrocarbons.

\section{SEISMOLOGY IN ҰAPAN}

The Earthquake of February 22, 1880.-The earthquake which occurred shortly after midnight on the morning of February 22 was the most severe since the opening of this country to foreigners. I have been so much in the habit of noting my watch during the frequent earthquake manifestations by day and night, that I am sure I must have been instantly awakened. My house was swaying to and fro, windows were rattling, timbers creaking, mortar falling, and pictures swinging violently. Although, as usual on such occasions, I was studying my watch by a night light, I meditated escape. After forty seconds the motion apparently subsided. There had been two distinct periods of maximum intensity. Taking my lamp, I tried to reach the door, but the motion was still so great that I had to stop, supporting myself against the wall. When I went down stairs to look at two long pendulums of 20 and 30 feet length respectively, I found them swinging in arcs of about 2 feet, having broken all the apparatus on the table over which they hung. IIitherto the pointers placed on heavy weights suspended by long wires have been regarded by me as motionless points during an earthquake, and I have been able to use them accurately on this assumption even for a shock which Palmieri's instrument indicates as $2 \mathrm{I}^{\circ}$, a shock which knocked down several chimneys. It would seem that in the last earthquake the house, instead of so to speak, "eating up" the vibrations, was forced into vibration itself. The period of this vibration was roughly noted by my neighbour, Mr. Thomas Gray, as nearly one second. At the lower end of one of these pendulums I have small pointers which scratch two smoked glass plates. These plates are caused to move away during an earthquake, so that relative vibrations are shown in two wavy lines. The direction of the first mark upon the plate tells the direction of the shock, and also the distance moved by the earth relatively to the steady pointer. The amplitude of the waves tells approximately what the movement has been during succeeding vibrations. From the number of waves upon a given length of glass we get the rate of yibration, and hence, knowing the velocity of transit, the true wave-length of the earthquake may be determined. As an example I may mention that an earthquake (December 3, 1879) registered by Palnieri's instrument as $18^{\circ}$, was recorded on 7 inches of one of my glass plates in a curve of seven very small waves, the amplitude of each of which was about $\mathbf{I ~ m m}$. Each wave was formed in half-a.second. The important deductions which may be drawn from even only one observation of this kind are obvious. The other pendulum I have used only for finding the greatest horizontal movement of an earth particle and its direction. Two pointers push against the motionless pendulum-bob when an earthquake occurs, and so they are moved in the stand which carries them, deflecting two suspended galvanometer mirrors, and readings of the amount of deviation of beams of reflected light are taken. I give some examples of the movement of the head of a pile which was driven deeply into the soft soil upon which Yedo is built :-

r. March 4, $1879,4.43$ p.m.-On the smoked glass the mark made was $3 \mathrm{~mm}$. long; $\mathrm{N}$. $10^{\circ} \mathrm{E}$. to S. $10^{\circ} \mathrm{W}$. Palmieri's instrument gives this shock of intensity $10^{\circ}$ from S.S.W. to N.N.E.

2. February I, I880.-Small shock. Mark $1.25 \mathrm{~mm}$. from N. $35^{\circ} \mathrm{W}$. to S. $35^{\circ} \mathrm{E}$. Palmieri's instrument gives intensity

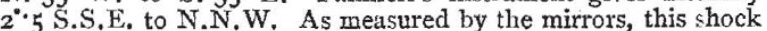
was $0^{\circ} 5 \mathrm{~mm}$., and there is reason to believe that the mirrors were more correct. The amplitude of swing, as indicated on the moving plates, was from $3 \mathrm{~mm}$. to $4 \mathrm{~mm}$. At the point, however, there seems to have been a motion of about ro $\mathrm{mm}$.

As my indicating apparatus was broken, I give the following record from two of Palmieri's instruments in the Government Observatory :-

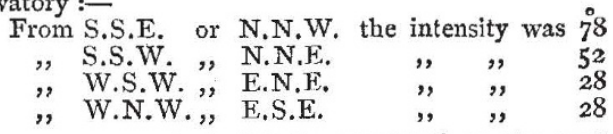

These measurements had to be computed, as the graduations of the instruments are only to $26^{\circ}$. The shaking seems to have had three periods. The first began at I 2 h. $49 \mathrm{~m} .22 \mathrm{~s}$., and lasted I4 seconds; the second began at I2h. 50m. I9s., and lasted Im. 26s.; the third began at I2h. 52m. 15s., and lasted 6 seconds.

On visiting Yokohama I found that the chief destruction had been amongst the houses belonging to Europeans. This is partly due to the Japanese houses being nearly as flexible as baskets, but it is also on account of the European houses being mostly buils on hills. Thus the houses built on the bluff, hills intersected by sharp steep valleys, and also many houses built along the creek have suffered ; the greater part of Yokohama is built on a plain of shingle, and the houses here escaped with small damage.

The edge of a declivity is like the last of Tyndall's row of boys, unsupported on one side, and therefore gets shot forwards. Tokei, Yokohama, Japan

\section{UNIVERSTTY AND EDUCATIONAL INTELLIGENCE}

CAMBRIDGE. - In the first half of the winter course of lectures given in connection with the Cambridge Local Lectures the attendance of about $I, 200$ persons, on subjects of physical science, out of a total of 3,570 , may be noted. In the second half of the session scarcely 400 were attending lectures on physical science subjects, but this was coincident with a general falling off after Christmas, to which bad weather, depression of trade, and political excitement may have contributed.

Another academic year has completely passed, and in the multitude of counsellors no relief has yet been given to those who desire freedom of choice of language studies and some chance for modern languages. The University still says : "If you have not the smattering of Greek we require, we will give you no degree unless you bring up Arabic or Sanskrit as an Oriental student."

A LIVERPOoL paper intimates that the movement for establish. ing a University College in that city is likely soon to be crowned with success. In the scheme which was approved at a town's meeting held some months ago it was proposed that seven professorships and two lectureships should be founded, and it was estimated that, independent of the cost of erecting college buildings, the amount required for the foundation of the college is an annual income of $3,000 \%$, or a capital sum of $75,000 \%$. The committee accordingly appealed for subscriptions, and the appeal has been responded to in such a hearty manner that there is every probability of the entire sum required being raised before long. Already $60,000 \%$. has been subscribed for the establishment of the college, the subscriptions including several of 10,000l. each. Lord Derby has subscribed 10,000\%. towards the founding of one professorship; a like sum has been given by Messrs. W., S. G., and P. H. Rathbone. Mrs. Grant of Rock Ferry has endowed another professorship with Io,oool.; Col. A. H. Brown and the Messrs. Crossfield have between them contributed ro, $000 \mathrm{l}$. for the founding of another chair; and it is believed a number of Scotchmen resident in the city will provide 
a similar amount for a similar purpose. Several other large subscriptions have been promised to the treasurer, Mr. Robert Gladstone, bringing the total up to the amount above stated.

\section{SCIENTIFIC SERIALS}

Bulletins de la Societed Anthropologic de Paris, tome 2, fasc. 4, 1879. - This closing number of the last year's Bulletins con. tains an interesting paper by $M$. Jacques Bertillon on the mean averages of life in the various grades of society among civilised races. Ilis paper refers specially to France, although it sup plies some comparative tables deduced from the mortality tables of other countries, while it principally aims at directing attention to the preventibility of numerous causes of early death. $-\mathrm{M}$. G. Iagncau, in presenting to the Society ithe mortality tables for Bclgium, drawn up by Dr. Janssens for 1878 , referred to the predominance of phthisis in male subjects in France since 1865 66 , females having before that period supplicd the larger number of deaths from pulmonary tuberculosis.-M. I.unier records the results of the official inquiry which he had been authorised to make in reference to the distribution of epilepsy in the various departments of France, and with regard to station, age, sex, S.c.-M. le Docteur G. Lc Bon gives an interesting report of his examination of the curious collection of skulls of celebrated men, now in the possession of the Paris Museum of Natural IIistory, which is believed to inciade those of Boileau, Dcscartes, and Gall. The mean cranial capacity for the forty-two skulls, when compared with that of forty two skulls of modern educated Parisians, was in excess of the difference between the latter and an equal number of negroes.-The present number of the Bulletins contributes little of importance to the literature of local French palxontology, the most interesting of such contributions being a paper by $\mathbf{M}$. Mortillet, who reports the discovery, by $\mathbf{M}$. Perron, of a funereal car with traces of human bones and textile fabrics in the tumulus, or barrow, known as la Motte at Apremont, in Hante-Saûne. - M. Verneau describes the Grotto de Voutre, in La Majenne, in which a skeleton, believed to belong to the Bronze age, has been found, while a similar discovery lias been made at Quevilly, near Rouen, as also at Cierges, wherc fragments of a dolichocephalic cranium of the neolithic type have been recovered. M. Millescamps has, moreover, drawn attention to the recent discovery by the Ablit Hamard, at Hermes (Oise) of cut flints in graves of the Merovingian age. 'The previous discovery between 1873 and 1875 of upwards of 20,000 flints in the Merovingian cemetery of Caranda has raised the question, which still awaits solution, whether these flints were deposited with the dead merely as objects with which the living had been most familiar, or whether their presence had any supposed protective action.-M. Zaborowski has laid before the Society the result of his examination of five Hakka skulls, .and communicated the information he had received from $M$. de Lagrenée, French Consul at Canton, in regard to the history and purc Chinese origin of the Hakkas, who have in all ages formed the active combative element in the Chinese system, and have in recent years constituted the kernel of the Taiping rebcl. lion.-The Abbć Durand describes a blonde African race, noticed near Laouga in 1562, and still traceable in Mozambique. - The nriginal site of the Aryan race has again been brought under discussion by A1. IIenri Martin, who now inclines to the opinion, supported by M. de L jfalvy, that a brown brachyccphalic Aryan branch took precedence in Asia of the blonde dolichocephalic Aryans.- lihe most important paper in the present volume is M. Paul Broca's " Etude des Variations craniométriques, et de lcur Influence sur les moyennes." To this is appended a valuable series of the means, variations, \&c., of the cranial measurement of heads belonging to all countries and various periods. $\rightarrow$ M. Ujfalvy explained his vieu's in regard to the opinion put forth by the Swedish anthropologist, Prof. G. Retrius, that Finland is occupied by two distinct races, the truc Fin, or Tawastc, and the Carelian, or Finlander.-M. Emile Soldi, in presenting to the Society his recent work on the proportions of Greek and Egyptian statues, took occasion to refute the opinion advocated by J). L.e Bon and M. Broca, that the Grceks followed Egyptian canons of taste in art, and that they took their models from foreigners, - M. Bataillard read a paper on the ancicnt workers in metals in Grecec, and endeavours to trace in the tinsmiths of Dodona the direct ancestors of the modern $\mathrm{T}$ :iganes, or gipsies.

Papers and Froceedings of the Rioyal Socicty of Tasmania for $1878 .-R$. M. Johnston, on the freshratcr shells of Tasmania; gives a list and describes scveral new species.-Rev. J. E. Tenison-Woods, on some new Tasmanian marine shells; describes a new gents, Iosepha, for a Cominella with a plait, and several new species. $-R$. M. Johnston, on certain tertiary and post-tertiary deposits on islands in Bass's Strait. - F. M. Bailey, remarks on the distribution and growth of Queensland plents. Kev. J. E. Tenison-Woods, on some Tasmanian freshwater univalves. $-F$. Abbott, on Cardurs arvensis.

\section{SOCIETIES AND ACADEMIES LONDON}

Royal Society, June I0.-_"On Bacterium fatidum: an Organism associated with Profuse Sweating from the Soles of the Feet." By George Thin, M.D. Communicated by Prof. Huxley, Sec.R.S.

The feet of certain individuals are characterised by a peculiar powerful and fotid odour, which is really connected with the moisture that soaks the soles of the stockings and the inside of the boots. The moisture, which comes from the skin of the soles, especially frum that of the heels, has no offensive smell whilst it is exuding, but it rapidly acquircs the characteristic odour when taken up by the stocking.

The fluid is an admixture of sweat with serons exudation from the blood, occurring in persons whose feet sweat profusely, and who, from much standing or walking, acquire an erythematous or eczematous condition of the skin of the soles, the local ec\%cma or erythema being favoured by the softening and maccrating effect of the sweat on the epidermis.

When s small portion of the sole of the wet stocking was teased out in water, the drop of water was found to be swarming with micrococci.

A second generation of the organism, which the author calls Bacterium fatidum, was obtained by placing a small piece of the wet stocking in a test-glass, charged with pure vitreous humour. This and succeeding generations werc cultivated at a temperature which varied between $94^{\circ}$ and $98^{\circ} \mathrm{F}$. The successive generations were obtained by inotulating pure vitreous humour, with requisite precantions.

In twenty-four hours the surface of the vitreous humour was always found covered with a delicate scum, which in forty-eight hours was compact and tolerably resistant.

In the scum of one day's igrowth and in the flaid below it organisms were found as cocci, single and in pairs, in transition stages towards rod formation, as single and jointed rods, and as elonga:ed single ruds. Many of the rods were actively motile.

The compact scum of two days growth was sufficiently resis. tant to be removed in an unbroken sheet. When disturbed by the needle it fell to the bottom of the glass. It was found to contain all the forms found in the twenty-four hours' growth, and in addition long unbroken rods in transition stages towards the formation of chains of spores.

Spores were also found lying beside the empty and partially empty sheaths from which they had been discharged. Groups of single spores and pairs, identical in size and appearance with those which had come to maturity (in the sheaths, were found mixed up with rods in all phases of development.

The first stage in the development of the organism is the formation of a pair from one coccus.

'The next stage is that in which the whole body is wedgeshaped, the round brightly refractive coocus being found in the thick end of the wedge. Another phase, which is probably the successor of the preceding one, is the appearance of a canoe shaped figure with the bright coccus in the centre.

Other appcarances connected with the early stage of dcvelop. ment, and probably following the wedge and canoe-shaped figures, show the organism developed into a staff-shaped body, containing two elements of very different refractive power. 'The coccus element is still slistinct and is brightly refractive, the other element is very slightly refractive and is secu as a dull shade, with bowever perfectly distinct outlines.

The coccus may be at onc end of the rod, two cocci may be in the centre close together with a prolongation of 'protoplasm on either side, or a central rod of prutoplasm may have a coccus at cither end.

In the next stage we have the formation of the rods characteristic of bacteria. The distinction between the coccus and the protoplasm becomes lost, although transitions are found in which faint differences of refraction still betray the two elements. The formation of rods of ordinary size, of long rods with 